\title{
The Legality of the Bowl Championship Series (BCS): Examining Pro-Competitive and Anti-Competitive Outcomes on Consumers and Competitors
}

\author{
Chad S. Seifried \\ Louisiana State University
}

\begin{abstract}
The formation of the Bowl Championship Series (BCS) was intended to produce entertaining match-ups and a national title game for the financial and public benefit of participants that the previous bowl systems could not arrange. However, disputes continued to rage about access and the selection criteria used to establish eligible teams for the various BCS games. This article reviews the Sherman Antitrust Act emphasizing the anti-competitive and pro-competitive effects of the BCS on Division I (FBS) members and college football fans primarily under the rule of reason test. Recent financial and product quality evidence regarding the pro-competitive and anti-competitive outcomes of the BCS will be introduced to lend support to those who prefer an alternative postseason arrangement for Division I (FBS). A brief review of the Lanham Act and Federal Trade Commission Act will also occur to further highlight how college football fans are important consumers to consider

for

potential

litigation.
\end{abstract}

Recent bi-partisan efforts in various United States (U.S.) Congressional Hearings (2003-2009) identified the Division I Football Bowl Subdivision's (FBS) Bowl Championship Series (BCS) as potentially a restraint of trade and in violation of federal antitrust law (Nixon, 2009; Pruitt, 2009; Seifried \& Smith, 2011). ${ }^{1}$ The arguments of the various House and Senate Committees focused on the denial of past

\footnotetext{
${ }^{1}$ a) Senate Committee on the Judiciary (2003); b) Judiciary Subcommittee on Antitrust, Competition Policy, and Consumer Rights (2005); c) House Committee on Ways and Means (2006); and the d) Energy and Commerce Subcommittee on Commerce, Trade and Consumer Protection (2009)
} 
and likely future opportunities for the non-charter member BCS affiliated conferences (i.e., Sun Belt Conference, Western Athletic Conference, Mountain West Conference, Mid-American Conference, and Conference USA) to secure national exposure and the significant revenue (i.e., $\$ 18$ million per institution) provided by the higher-profile BCS bowls (i.e. Rose presented by Visio, Discover Orange, Tostitos Fiesta, Allstate Sugar, and National Championship). Other issues introduced by the committees discussed the bowl arrangement, the cartel structure of the BCS, and the selection process used to choose the BCS bowl participants along with its impact on consumer choices and preferences as compared to other alternative postseason models (BCS or bust, 2003; The Bowl Championship Series, 2009; Competition in college, 2003; Determining a champion, 2005; Hearing on BCS, 2009).

The formation of the BCS was intended to help meet college football consumer interests in the matching of a 'true' national title game for the Division I (FBS) level (2009-2010 BCS Media Guide, 2009). It also aimed to produce entertaining match-ups for the financial and public benefit of participants that the previous bowl systems (i.e., Bowl Coalition and Bowl Alliance) could not arrange (2009-2010 BCS Media Guide, 2009). However, disputes continued to rage about access and the selection criteria used to establish eligible teams for BCS bowl games and the national title contest. As an example, the subjective ratings from the Harris Interactive Poll, USA Today Coaches Poll, and the algorithms of six different computer polls (i.e., Jeff Sagarin, Anderson \& Hester, Richard Billingsley, Colley Matrix, Kenneth Massey and Dr. Peter Wolfe), components of the current BCS selection formula, provided only the University of Oregon (12-0) and Auburn University (13-0) an opportunity to play for the 2010 BCS national title. This occurred despite the fact that Texas Christian University (TCU) also finished undefeated (13-0) and enjoyed a better preseason ranking (i.e. \#6 Associated Press and \#7 USA Today) than both Oregon (\#11 Associated Press and USA Today) and Auburn (\#22 Associated Press and \#23 USA Today). Similar disputes occurred in 2009 when other charter-member BCS schools, the University of Alabama (13-0) and University of Texas at Austin (13-0), were selected to play for the BCS national title although several other undefeated teams (i.e., TCU 12-0, University of Cincinnati 12-0, and Boise State University 13-0) also finished the regular season 
undefeated. $^{2}$ Nearly identical debates about the legitimacy of BCS appeared annually since its launch in 1999.

This article will review the Sherman Antitrust Act emphasizing the anti-competitive and pro-competitive effects of the BCS on Division I-FBS members and college football fans primarily under the rule of reason test. Recent financial and product quality evidence regarding the pro-competitive and anti-competitive outcomes of the BCS will be introduced to lend support to those who prefer an alternative postseason arrangement for Division I (FBS). A brief review of the Lanham Act and Federal Trade Commission Act will also occur to further highlight how college football fans are important consumers to consider for potential litigation. This inquiry respects these various acts because the courts will likely hear several different approaches to review any possible restraint of trade and consumer fraud created by the BCS (Rogers, 2008).

The Sherman Antitrust Act appears applicable to review because the BCS and the National Collegiate Athletic Association's (NCAA) various member institutions organize college athletics as commercial spectacles and not as simple amateur competitions. Through this joint venture (i.e., horizontal agreement) an entertainment product is established (i.e., BCS Bowls and BCS National Championship Game) for the realization of commercial benefits. Consumer protection laws (e.g., Lanham Act and Federal Trade Commission Act) appear useful to review primarily because the BCS advertises and produces a national championship game and other lucrative contests which exclude other eligible and equally worthy teams from competition consumers may prefer (Allred, 2010). Schmit (2007) suggested this practice "at its very core violates" the principles of fundamental fairness and consumer fraud "without providing the necessary justifications under the Sherman Act" (p. 219). The BCS selection and arrangement process has not seen a judicial review through antitrust or consumer protection law challenges despite the fact that the BCS may restrict consumers from enjoying the best quality match-ups and confuse consumers through advertising the BCS title game as the producing the definitive Division I-FBS 'national champion' (Seifried \& Smith, 2011). The unequal financial rewards for BCS selection given to non-BCS schools and the lack of a matching reward for regular season performance also could be 'flagged' for

2 Automatic-qualifying charter member institutions include the Atlantic Coast Conference, Big East, Big 12, Big Ten, Pac-10, and Southeastern conferences, and Notre Dame. 
conduct detrimental to the output and product quality of the Division IFBS and non-BCS members. ${ }^{3}$ These points are particularly interesting if other alternative postseason formats present a less restrictive means to conduct the activities of Division I-FBS football.

\section{Explanation and Connection to the Sherman Antitrust Act}

The United States enjoyed roughly 120 years of case law which applied the Sherman Antitrust Act to examine possible anti-competitive behaviors and activities by competitors. The Sherman Antitrust Act was designed to help protect and preserve competition in a free market capitalist economy (Fisher \& Phillips, 2003). Free and open competition drives opportunities for growth and innovation to enhance both products and consumer welfare (Fisher \& Phillips, 2003). The Sherman Antitrust Act evolved to focus on consumer welfare so any antitrust law violations have to prove consumer harm in addition to simple harm suffered by the industry competitors (Werden, 2007). This point is critical to acknowledge in any BCS-antitrust hearing and for any advocate of the either side.

Section 1 of the Sherman Antitrust Act prohibits an unreasonable restraint of trade from multiple competitors who cooperate or conspire together for their own mutual economic benefit at the expense of others (Allred, 2010; Fenasci, 2004; Moreland, 2005; Nixon, 2009; Pruitt, 2009; Rogers, 2008). Examples of conspiracies that harm consumers include price fixing, bid rigging, and the division a market (e.g., BCScharter and non-BCS institutions). The reach of Section 1 includes activities of nonprofit organizations, including institutions of higher learning (United States v. Brown University, 1993; United States v. Realty Multi-List, 1980). Section 2 of the Sherman Act forbids monopolies or attempts to monopolize an industry from other single firms or organizations from controlling prices or excluding competition (Allred, 2010; Fenasci, 2004; Moreland, 2005; Nixon, 2009; Pruitt, 2009; Rogers, 2008). The prevention of monopolies serves to help assure the abuse of market power does not occur at the expense of other

\footnotetext{
${ }^{3}$ TCU (MWC) and Boise State (WAC) were rewarded with payouts of $\$ 9.8$ million and $\$ 7.8$ million respectively in the 2010 Fiesta Bowl. The Big Ten and the SEC collected over $\$ 22$ million while the remaining four BCS-charter conferences were awarded $\$ 17.7$ million each for their BCS appearances (Non-BCS conferences, 2010).
} 
competitors and the consumers (Moreland, 2005; Nixon, 2009; Pruitt, 2009; Rogers, 2008).

Intent to monopolize, bid rig, market divide, and control or fix prices would need to be proven through the conduct and content of the BCS agreement. In this instance, advocates for non-BCS schools would have to prove BCS-charter members implemented specific barriers of inclusion to $\mathrm{BCS}$ games and conspired through collusion to restrict the eligibility of non-BCS schools from enjoying a legitimate share of the market and other associated benefits resulting from participation in those events (Allred, 2010; Fenasci, 2004; Moreland, 2005; Nixon, 2009; Pruitt, 2009; Rogers, 2008). Known also as a cartel, this activity limits product output and quality for competitors and consumers through controlling inputs which to drive up revenues for the privileged. The BCS may be viewed as a cartel because it creates value for BCS institutions through the monopolization of television contract agreements, gate receipts, merchandising and licensing fees, and school notoriety (Thieme, 2007). The revenues in turn help BCS institutions secure and maintain a high level of quality coaching and student-athletes, improve academic and athletic facilities, and acquire the latest and best equipment to maintain their competitive advantage over non-BCS schools (Seifried, 2011; Seifried \& Smith, 2011). Interestingly, Fizel and Bennet (2001) proposed the NCAA serves to institutionalize the "... foundations for cartel control of college sports," (p. 323). The cartel structure of the NCAA is established through conference agreements to produce a specific product from athletic competitions (Fizel \& Bennett, 2001; Thieme, 2007).

The financial evidence of the cartel activity is obvious. As an example, the 2009-2010 NCAA Postseason Football Finances Report's (2010) Summary of Revenue and Expense by Conference revealed approximately $\$ 237$ million in total bowl revenue was produced for the 2009-2010 bowl season. BCS-charter institutions gained roughly $\$ 198$ million of that figure (i.e., 83.6\%) while non-BCS schools earned (i.e., $\$ 39$ million). The subsections on the BCS Revenue Distribution also illustrated the 24 bowl games played between the 2005/2006 and $2009 / 2010$ bowl seasons produced a total of $\$ 717,639,147$ million (i.e., average of $\$ 143,527,829$ per season) for the NCAA participating institutions to share. BCS-charter institutions collected $\$ 621,675,447$ (i.e., 86.6\%) while non-BCS (Division I-FBS) schools accrued a mere $\$ 86,963,700$ (i.e., $12.0 \%$ ). The non-BCS label or stigma created by the 
BCS and these financial disparities has been identified by several works as potentially evoking a negative attitude for the recruiting of players, coaches, non-student-athletes, alumni, and media support (BCS or bust, 2003; The Bowl Championship Series, 2009; Competition in college, 2003; Determining a champion, 2005; Hearing on BCS, 2009; Schmit, 2007; Seifried \& Smith, 2011). Therefore, non-BCS charter schools face increasing difficulties trying to maintain and produce a quality product the college football fans can embrace for consumption (Seifried \& Smith, 2011).

Importantly, the courts will be concerned with how this chasm in revenue distribution and image injures consumers (e.g., increased prices and reduced output) and their choices or preferences as compared to other postseason alternatives under the Sherman Antitrust Act (Fenasci, 2004; Pruitt, 2009; Warmbrod, 2004). In essence, the courts will likely ask if consumers are presented with the best possible quality of product and output at the best price through the restrictions the BCS imposes on open competition toward competitors. The courts will also consider under the Sherman Antitrust Act if the BCS produces consumer harm by disseminating that their product matches the best teams and generates a true national champion better than other postseason options (Fenasci, 2004; Pruitt, 2009; Seifried \& Smith, 2011; Warmbrod, 2004). The Supreme Court demonstrated a willingness to take such a perspective in International Boxing v. United States (1959) when they positioned championship contests as separate events from other contests. In their opinion, the court offered that payout differences associated with those activities communicated a certain quality of output to consumers and that those events exceed general non-title match-ups.

Based on this brief review, the Sherman Antitrust Act appears to require a detailed and thorough test on a series of complex items regarding consumers and the behavior of the BCS-charter institutions within that market. The federal courts will look to utilize either the per se, quick look, or rule of reason test to determine the function and nature of market restraints and their impact on competitors and consumers. Below is a review of the various application tests. 


\section{Antitrust Tests}

\section{Per Se and Quick Look Tests}

Fenasci (2004) described the per se test as looking for "manifestly anticompetitive" behaviors (p. 978). This is best defined in Northern Pacific Railway Co. v. United States (1958) as the Supreme Court noted, "There are certain agreements or practices which because of their pernicious effect on competition and lack of any redeeming virtue are conclusively presumed to be unreasonable and therefore illegal without elaborate inquiry as to the precise harm they have caused or the business excuse for their use" (p.5). Again, those behaviors typically include price fixing, tying arrangements, market allocations, and group boycotts (Fenasci, 2004). Schmit (2007) identified the quick look analysis as primarily focused on whether or not anti-competitive effects significantly outweigh pro-competitive outcomes and if specific activities involve potential anti-competitive behavior that exceed an acceptable level of obviousness. As an example, in California Dental Association v. FTC (1999) the court showed the quick look analysis as applicable if "... an observer with even a rudimentary understanding of economics could conclude that the arrangements in question would have an anticompetitive effect on customers and markets" (p. 771).

The quick look and per se tests start with the assumption that a behavior is unreasonable upon which the defendant then must show procompetitive justification for this practice (California Dental Association v. FTC, 1999). Should those reasons be perceived as reasonable by the court, the plaintiffs must provide more economic evidence to show obvious damages and harm to competitors and consumers (Warmbrod, 2004). The courts will not likely use the per se or quick look analysis and will be more likely to use rule of reason test due to the incredible complexity and nature of the BCS product (California Dental Association v. FTC, 1999). In essence, the quick look and per se tests are likely too rudimentary for a thorough review because valid arguments can be used by either side of the BCS debate and an adequate assessment of pro-competitive vs. anti-competitive points is not performed to make for an obvious presentation or decision (Warmbrod, 2004).

Take for example the BCS governance structure; it shows BCScharter conferences and Notre Dame University as dominating the voting 
process within the BCS arrangement. All other non-BCS institutions do not share enough strength to oppose any collective effort raised by the charter-member BCS institutions and their representatives. This arrangement creates an opportunity for the BCS-charter schools to boycott the thoughts and opportunities of the non-BCS institutions and to exercise power at their discretion to meet their own interests. The collective action by the BCS-charter institutions interferes with the ability of non-BCS schools to seize opportunities to compete in the BCS bowl and Division I-FBS market. This appears as an overtly illegal restraint of trade and inherently anti-competitive. Again, as previously noted, boycotts previously established in a similar manner have been classified in violation of Section 1 of the Sherman Antitrust Act. The collective history of BCS-charter member institutions appears to support the assumption that BCS institutions sought to boycott the influence of non-BCS schools. However, the group boycott perspective may be illegitimate because collaboration is important for the actual creation of the college football game product (i.e. horizontal agreements) and various BCS events. Non-BCS schools are also not technically excluded from national championship and BCS bowl opportunities because they are members of the BCS agreement and agreed to participate under a certain set of prescribed rules (2010-2011 BCS Media Guide, 2010). Thus, without more balancing of pro-competitive vs. anti-competitive effects, like that offered in the rule of reason test, it is difficult for courts to deduce if the BCS is in violation of the Sherman Antitrust Act.

\section{Rule of Reason Test}

The rule of reason test thus values the facts and the nature of the business, history of the decision to restrain, and the reasons for the restraint. This perspective was previously shared by Judge Brandeis in Board of Trade of Chicago v. United States (1918) where he decided:

The true test of legality is whether the restraint imposed is such as it merely regulates and perhaps thereby promotes competition or whether it is such as may suppress or even destroy competition. To determine that question the court must ordinarily consider the facts peculiar to the business to which the restraint is applied; its condition before and after the restraint was imposed; the nature of the restraint and its effect, actual or probable. The history of the restraint, the evil believed to exist, the reason for 
adopting the particular remedy, the purpose or end sought to be attained, are all relevant fact (p. 246).

Importantly, Judge Brandeis showed the pro-competitive and anti-competitive facts particular to a specific situation are necessary to consider for a legitimate antitrust debate on the BCS. In the Board of Regents of the University of Oklahoma v. NCAA (1983), the court similarly favored the rule of reason test over the other approaches due to the complexity associated with the horizontal trade agreements necessary to sustain and maintain the existence of college football. Ultimately, in the NCAA v. Board of Regents (1984) the court opposed the activities of the NCAA because they remained unresponsive to consumer preferences through the facts presented. Specifically, within his review, Justice Stevens described the cooperation of the NCAA institutions as a joint venture which created commercial products using distinctive eligibility guidelines.

Under the rule of reason test, the plaintiffs would be required to demonstrate the BCS selection process and arrangement produced a substantial and adverse effect on non-BCS schools and consumers alike through price fixing or the deterioration of product quality and/or services (Warmbrod, 2004). Defendants in the rule of reason analysis can argue for or identify how the pro-competitive aspects of their collective behavior outweigh or justify the business purpose of their actions over the anti-competitive restraints. Should this be demonstrated by the defendants, the plaintiffs then are obligated to show the goals of the restraint could be achieved through a less restrictive means or alternative course of action (Allred, 2010; Nixon, 2009; Seifried \& Smith, 2011; Warmbrod, 2004). In the end, a court hearing the antitrust challenges associated with the BCS would have to balance the exclusion effect it burdens non-BCS schools with against the pro-competitive benefits the arrangement allegedly produces. Those effects on consumers would also need to be addressed along with the potential outcomes other alternative courses of actions (e.g., playoff or less restrictive means) could produce.

This work accepts the perspective that the BCS is an improvement over the previous bowl system; this will be highlighted below. However, it should be recognized as not maximizing the potential of the college football postseason for all Division I (FBS) participants and consumers. Furthermore, BCS schools should not be viewed as creating a wholly better product for consumers than non-BCS 
institutions. The following describes the possible pro-competitive and anti-competitive effects of the BCS the courts will likely hear along with various counterpoints which lend support to anti-competitive nature of the BCS.

\section{Pro-Competitive and Anti-Competitive Points of Interest on the BCS}

Congressional reports and public comments overwhelmingly show BCS advocates and university presidents or chancellors wish to avoid a longer extended season for several reasons (BCS or bust, 2003; The Bowl Championship Series, 2009; Competition in college, 2003; Determining a champion, 2005; Hearing on BCS, 2009; Seifried, 2001; Seifried \& Smith, 2011). First, they worry about the possible toll any alternative postseason format (i.e. playoff) would impose on studentathletes during final exams and the quality of work they might produce toward the end of the semester (Rogers, 2008; Seifried, 2011; Seifried \& Smith, 2011). Next, these same BCS advocates and university presidents or chancellors also desire to maximize the number of postseason opportunities for their institution, student-athletes, and fans (Fenasci, 2004; Seifried, 2011; Warmbrod, 2004). Other alternative formats would, in their opinion, doom the tradition associated with the bowl games along with the quality of play during the regular season (BCS or bust, 2003; The Bowl Championship Series, 2009; Competition in college, 2003; Determining a champion, 2005; Hearing on BCS, 2009; Seifried, 2011; Seifried \& Smith, 2011). In turn, this would ultimately lead to the dissolving of the unique experiences bowl games provide to student-athletes and members of the college football fan nation during the holiday season along with the benefits they provide host communities and charities (Seifried, 2011; Seifried \& Smith, 2011). Proponents of the BCS additionally promoted it as adjustable to market demands (e.g., number of qualifying teams and bowl games) to reassure consumer preferences are met (Pruitt, 2009). Furthermore, they accepted it would be too logistically challenging to administer and manage a Division I (FBS) national tournament (Nixon, 2009; Seifried, 2011). As an example, Fenasci (2004) suggested "there is the obvious problem of selecting which sixteen teams will be chosen to go to the playoffs" ( $p$. 995).

Although legitimate, these arguments are open to criticism and counterpoints by BCS opponents. For instance, Fenasci (2004) is correct 
about similar arguments regarding protests associated with the selection of a playoff bracket but not in frequency or amplitude as compared to the annual BCS debate. The NCAA men's basketball tournament appears as a vision of democracy because "... the best teams in the nation have to accept the challenge of all their qualified peers" and much of the media storm settles about those left out once the games begin (Warmbrod, 2004, p, 340). This makes it a less restrictive alternative the Division I (FBS) could embrace. Next, Tulane Law Professor, Gary Roberts, stated in a symposium about the state of affairs in Division I (FBS) athletics that "... you don't need to do away with the bowl system in order to have a playoff system that produces a national champion. There have been a variety of different plans put forward that would preserve the bowl system and still provide for a national championship" (Legal Ramifications, 2005, p. 465). Pruitt (2009) and Seifried (2011) also acknowledged multiple options exist which incorporate the bowls and non-BCS schools into an alternative postseason arrangement that modern communication and transportation technology can support for logistical success. The management of the various lower divisions of college football (i.e., Division I-FCS, II, and III) playoff shows this is possible too.

The loss of one tradition may also provide the opportunity to start another similar to the men's basketball spectacle without losing the uniqueness of the bowl arrangement or the importance of the regular season. In fact, the regular season with an alternative postseason format (i.e., elimination tournament) could replace the complacency frequently associated with the FBS regular season because each regular season game would significantly alter seeding and potential home field award opportunities under many playoff formats for many without affecting the bowl prospects for others in a concurring bowl system. Reduced BCS television ratings and average attendance totals between 2007 and 2011 indicate the strength of the current FBS regular season may not be strong because of the lack of 'buzz' created (Table 1). The addition of the 'national championship game' also has not generated the boost it claimed consumers would embrace because the average television ratings and attendance between 2007 and 2001 are less than most years prior to that event (TV Ratings, 2011). A less restrictive alternative may prompt better ratings and attendance for the Division I-FBS postseason and meet consumer preferences. 
Table 1

BCS Television Ratings and Attendance 2007-2011

\begin{tabular}{|c|c|c|c|}
\hline Bowl Game & Team & TV Rating & Attendance \\
\hline $\begin{array}{l}2011 \\
\text { Championship }\end{array}$ & $\begin{array}{l}\text { Oregon- } \\
\text { Auburn }\end{array}$ & 15.29 & 78,603 \\
\hline Fiesta & $\begin{array}{l}\text { Connecticut- } \\
\text { Oklahoma }\end{array}$ & 6.15 & 67,232 \\
\hline Orange & $\begin{array}{l}\text { Stanford- } \\
\text { Virginia Tech }\end{array}$ & 6.75 & 65,453 \\
\hline Rose & $\begin{array}{l}\text { Wisconsin- } \\
\text { TCU }\end{array}$ & 11.26 & 94,118 \\
\hline Sugar & $\begin{array}{l}\text { Ohio State- } \\
\text { Arkansas }\end{array}$ & 8.2 & 73,879 \\
\hline $\begin{array}{l}2010 \\
\text { Championship }\end{array}$ & $\begin{array}{l}\text { Alabama- } \\
\text { Texas }\end{array}$ & 17.17 & 94,906 \\
\hline Fiesta & $\begin{array}{l}\text { Boise State- } \\
\text { TCU }\end{array}$ & 8.23 & 73,227 \\
\hline Orange & $\begin{array}{l}\text { Iowa-Georgia } \\
\text { Tech }\end{array}$ & 6.8 & 66,131 \\
\hline Rose & $\begin{array}{ll}\text { Ohio } & \text { State- } \\
\text { Oregon } & \end{array}$ & 13.18 & 93,963 \\
\hline Sugar & $\begin{array}{l}\text { Cincinnati- } \\
\text { Florida }\end{array}$ & 8.5 & 65,207 \\
\hline $\begin{array}{l}2009 \\
\text { Championship }\end{array}$ & $\begin{array}{l}\text { Florida- } \\
\text { Oklahoma }\end{array}$ & 15.8 & 78,468 \\
\hline Fiesta & $\begin{array}{l}\text { Texas-Ohio } \\
\text { State }\end{array}$ & 10.4 & 72,047 \\
\hline Orange & $\begin{array}{l}\text { Va.Tech- } \\
\text { Cincinnati }\end{array}$ & 5.4 & 73,602 \\
\hline Rose & $\begin{array}{l}\text { Southern Cal- } \\
\text { Penn State }\end{array}$ & 11.7 & 93,293 \\
\hline Sugar & Utah-Alabama & 7.8 & 71,872 \\
\hline $\begin{array}{l}2008 \\
\text { Championship } \\
\text { Game }\end{array}$ & LSU-Ohio St. & 14.4 & 79,651 \\
\hline Rose & $\begin{array}{l}\text { Southern Cal- } \\
\text { Illinois }\end{array}$ & 11.11 & 93,923 \\
\hline
\end{tabular}




\begin{tabular}{|l|l|l|l|}
\hline Fiesta & $\begin{array}{l}\text { W. Virginia- } \\
\text { Oklahoma }\end{array}$ & 7.7 & 70,016 \\
\hline Orange & $\begin{array}{l}\text { Kansas-Va. } \\
\text { Tech }\end{array}$ & 7.4 & 74,111 \\
\hline Sugar & $\begin{array}{l}\text { Georgia- } \\
\text { Hawaii }\end{array}$ & 7 & 74,383 \\
\hline $\begin{array}{l}\mathbf{2 0 0 7} \\
\text { Championship } \\
\text { Game }\end{array}$ & $\begin{array}{l}\text { Florida-Ohio } \\
\text { St. }\end{array}$ & 17.4 & 93,852 \\
\hline Rose & $\begin{array}{l}\text { Southern Cal- } \\
\text { Michigan }\end{array}$ & 13.94 & 93,852 \\
\hline Fiesta & $\begin{array}{l}\text { Boise St.- } \\
\text { Oklahoma }\end{array}$ & 8.4 & 73,719 \\
\hline Orange & $\begin{array}{l}\text { Louisville- } \\
\text { Wake Forest }\end{array}$ & 6.98 & 74,470 \\
\hline Sugar & $\begin{array}{l}\text { Notre Dame- } \\
\text { LSU }\end{array}$ & 9.29 & 77,781 \\
\hline Average & 10.25 & 78,710 \\
\hline
\end{tabular}

Note: This information reflects Nielsen Media Research ratings previously published by the Associated Press and USA Today.

The concern for the academic welfare of student-athletes is also commendable but the same interest is not shown for other sports governed by the NCAA or other divisions of football (i.e., Division IFCS, II, and III) which allow playoff competition to occur simultaneously during the conclusion of the academic calendar. Former NCAA President Miles Brand stated the concerns for the academic welfare of student-athletes were a weak defense to this point in his statements to Congress (Brand, 2006; Competition in College, 2003; Seifried \& Smith, 2011). In essence, Brand positioned little merit to this argument because of advances in academic services. Furthermore, he admitted the multi-week football playoff event would likely also occur primarily on weekends which did not conflict with a student's class attendance or exam schedule. Former Brigham Young University (BYU) head coach LaVell Edwards supported this position in his 2003 Congressional testimony when he noted that his team's 15-game schedule (i.e., 14-1 record) in 1996, the longest in Division I (FBS) 
history, did not adversely affect their academic performance his team's injury rate either (BCS or bust, 2003).

The idea that non-BCS schools will receive a free ride also permeates the thoughts of many BCS advocates as a reason to oppose a national elimination tournament (Seifried, 2011). As an example, Pruitt (2009) argued non-BCS institutions generally possess smaller fan nations and thus cannot contribute the same level of capital to college football and bowl communities as traditional powers from BCS conferences. Allowing non-BCS institutions to enjoy the same rights and benefits provided by the BCS essentially gives these schools a share they have not earned or deserve and may damage bowl communities and their effort to improve their local economy (Pruitt, 2009). The BCS created conditions which guaranteed higher financial returns and participation opportunities for BCS-charter institutions and bowl communities because of their perceived investment into college football (Seifried \& Smith, 2011). BCS advocates contend these financial rewards guaranteed annually to BCS-charter institutions and bowl communities are the result of their hard work (Seifried \& Smith, 2011). These established practices potentially pass the rule of reason analysis because they produced procompetitive effects for BCS-charter schools, bowl communities and serve to reduce and/or eliminate 'free rides' demanded by others (Pruitt, 2009).

Nonetheless, the record shows non-BCS schools can compete too and may be adversely affected by the BCS restraints (Seifried \& Smith, 2011; Warmbrod, 2004). In an effort to determine if this scenario continues to exist for this article, the author of this paper discovered that non-BCS schools, with 2 or fewer losses, won 79 of the $110(72 \%)$ contests they played against BCS institutions between 1991 and 2010 . Furthermore, these BCS opponents collectively won over $54 \%$ of their games (623-525) which demonstrate these non-BCS schools were deserving of a top-tier bowl and that the BCS arrangement may be rigged to prevent consumers from enjoying the best postseason product and output. Non-BCS schools finishing in the top ten of the BCS rankings between 2006-2010 also played 33 out of conference contests but only five were home games against BCS institutions. On six other occasions those high-rankings non-BCS teams played on the road or at neutral site locations winning all 11 games in total (i.e., home, road, and neutral). Traditionally lower performing BCS schools, opponents of the BCS will point out, should not be more deserving than all non-BCS schools 
because they likely do not invest to compete but instead invest to simply field a team to share in the significant perks of BCS affiliation (Seifried \& Smith, 2011).

It is important to note that non-BCS institutions achieved Division I (FBS) status because they met all the criteria for participation as required by the NCAA (2011-2012 Division I manual, 2011). For these institutions, this means they devoted a substantial amount of their time, energies, and money toward fielding at least 16 teams (with eight female), paying annual dues $(\$ 1,800)$, and providing $200+$ grant-in-aids or spending $\$ 4$ million+ toward grant-in-aids (NCAA Membership Requirements, 2009). Frequently, men's basketball and/or football are the only two which generate a revenue surplus for non-BCS Division I (FBS) institutions but this is not enough to help these institutions operate in the black. The typical athletic budget deficit for all Division I (FBS) institutions is roughly $\$ 8$ million (Fulks, 2009). Therefore, withholding and restricting opportunities from non-BCS schools and requiring them to accept a different reward for BCS participation appears illegitimate for the NCAA to support and as a prompt to search for a less restrictive alternative because many non-BCS schools invested in fielding highperforming teams for Division I.

Other evidence that Division I- FBS college football is an elitist type of activity is strong. Regularly non-BCS institutions with one or no losses failed to receive an invitation to a BCS bowl game between 1998 and 2010 despite the fact that BCS conferences frequently send teams with 2 or more losses to those contests. ${ }^{4}$ As an example, Sugar Bowl Executive Director, Paul Hoolahan, admitted in 2001 that Brigham Young University (BYU) was removed from consideration for their bowl game due to marketability despite the fact they finished 12-1 during the regular season (Schmit, 2007). Former BYU head coach LaVell Edwards criticized this practice. Specifically he offered, "The organizers of these bowl games extend invitations to the second place teams from the allied conferences...non-BCS teams then must go to cities not as appealing as Miami and New Orleans, making it difficult to attract alumni and their fan base to travel" (BCS or bust, 2003 p. 61). From his testimony, Edwards suggested non-BCS schools might produce higher television and attendance averages for the BCS if their fans were provided with the

\footnotetext{
${ }^{4}$ Between 1998 and 2010 the record of BCS schools with two or more regular season losses invited to BCS bowl games is 19-33.
} 
opportunity to travel to a more preferred and deserving location. Furthermore, Edwards argued the host communities would meet their local consumer demands and likely that of college football fans in general because non-BCS schools might possess a better product than other BCS invitees.

BCS supporters would next likely highlight their agreement provides an opportunity for a national title game which the previous bowl system could not guarantee. Therefore, consumers are not harmed but rewarded with the BCS arrangement. Expectedly, non-BCS institutions and consumers regularly counter that the two BCS title game participants and likely other BCS bowl game teams are chosen from a select small pool of schools which does not include them or their preferences (Seifried \& Smith, 2011). In essence, the BCS consistently failed to select the ten most deserving teams for its post-season arrangement of games and likely does not identify the two best teams for the championship game (Pruitt, 2009). The combination of these factors make the regular season irrelevant for some because the rules are set-up to favor the traditional powers.

The at-large qualification standard regularly assures this point as it favors BCS-charter member institutions. Eligibility for the at-large 'election' process concerning the various BCS games occurs well before the start of the season due to preseason ranking biases and restrictions non-BCS schools suffer under related to their schedule of opponents (Seifried \& Smith, 2011). For instance, it is difficult for non-BCS schools to schedule home games against BCS schools. A review of these schedules, by the author of this paper, found that over the last five years (2006-2010) for the top ten teams of the BCS during the final week of the regular season demonstrates this point. For instance, out of a possible 165 total out of conference games, BCS schools played on the road at non-BCS institutions 11 times and scheduled only five neutral site showdowns. Schmit (2007) similarly reported that between 1999 and 2002 top ten BCS teams played 65 home games against non-BCS schools while only playing 11 road games. The home field advantage BCS programs enjoy serves to decrease the likelihood that non-BCS schools can win at-large opportunities to join the BCS (Moreland, 2005).

Advocates of the BCS will point out the BCS selection formula and criteria are objective but anti-competitive proponents can argue it is illegitimate (Seifried, 2011; Seifried \& Smith, 2011). For example, the strength of schedule exists as a barrier to non-BCS schools attempts to 
improve their BCS standing (Stern, 2006). In essence, non-BCS schools are left to decide between scheduling other non-BCS teams or traveling to BCS schools for paydays they are desperate for due to the increased costs of running Division I athletics. Next, the computer polls, although providing an objective calculation of a team's ability versus other peer institutions, also do not use algorithms to create those rankings that involve all the necessary and legitimate information to create an unbiased measure of ability. For instance, although the actual algorithms for each of the various six computer polls used in the BCS rankings is unknown, there are certain components removed from consideration which could significantly change the view or ranking of institutions. As an example, margin of victory has shown to be statistically significant in predicting the outcome of contests (Miles, Fowks, \& Coulter, 2010; Stekler, Sendor, \& Verlander, 2009; West \& Lamsal, 2008).

For political reasons, the margin of victory omponent has been removed from the various computer polls used by the BCS. Specifically, the leadership of college football worried teams would "run up" the score on opponents to help their computer ranking. Under United States v. Realty Multi-List (1980) the BCS would need to refine its selection criteria and procedures to pass the courts inquiry regarding the legitimacy of the restrictions. Furthermore, the BCS would likely need to choose criteria that are statistically significant toward producing a more unbiased pool of at-large teams during the consideration stage of BCS selection process. This is the same at-large process which interestingly limited from consideration a third high ranking team from BCS conferences despite a final top ten BCS ranking (e.g., University of Wisconsin \#7- 2006, University of Missouri \#6- 2007, Texas Tech University \#7- 2008, and Michigan State University \#9- 2010) and most often a second non-BCS school (e.g., Boise State \# 9- 2008 and Boise State \#10-2010) regardless of the record or ranking of those receiving bids. The disruption of consumer welfare is readily apparent under these conditions because the best teams and postseason match-ups cannot be assured under the BCS agreement and ranking formula.

Finally, true economic output has been a measure used by both proponents and opponents of the BCS. Supporters of the BCS present several pro-competitive effects such as the increased number of bowl games since the invention of BCS and the number of BCS opportunities for non-BCS institutions from resulting modifications to the system (Seifried \& Smith, 2011). The increased number of bowl games and the 
relaxing criteria for BCS bowl game eligibility have steadily provided more revenue opportunities to non-BCS schools (Seifried \& Smith, 2011). However, the percentage of revenue distributed and resulting financial chasm is essentially the same as the previous bowl models. In analyzing the revenue distribution of all payouts since 1902, the author of this paper found that most new bowl opportunities go to BCS schools and that non-BCS schools only accrued approximately $8.4 \%$ or $195,000,000$ of the total bowl revenue available (i.e., $\$ 2.3$ billion) from current bowl games since the inception of the first BCS contests in 1999. Additionally, the analysis revealed that prior to the establishment of the BCS, non-BCS schools secured only about $7.3 \%$ or $\$ 91,000,000$ of the almost $\$ 1.25$ billion available from the current and extinct bowl games.

The economic impact of bowl games on host communities is also highlighted by BCS advocates. For example, Derrick Fox (Chief Executive Officer and President- Alamo Bowl) posited the bowls will collectively provide host communities roughly $\$ 1.1$ billion and over the next "10 years $\$ 2.2$ billion to more than 100 institutions of higher education" (Determining a champion, 2005, p. 41). Kevin Weiberg (Commissioner- Big 12 Conference) likewise offered the Sugar Bowl in January 2005 "created an economic impact of nearly $\$ 210$ million for the city of New Orleans and the state of Louisiana and that state and local governments realized nearly $\$ 16$ million in tax revenues as a result of the game" (Determining a champion, 2005, p.19). Still, none of these individuals mentioned or acknowledged the economic impact one additional playoff game would mean to a local campus community in a different postseason arrangement or speculated about the prospects a playoff might mean to NCAA coffers or host cities.

Speculation about the prospects of a possible elimination tournament is considered illegitimate by BCS proponents (Seifried, 2011, 2012; Seifried \& Smith, 2011). Specifically, they argue any financial predictions and media successes are not assurances and the bowl system provides financial guarantees that athletic departments need to continue intercollegiate programming (Seifried, 2011, 2012; Seifried \& Smith, 2011). However, opponents to the BCS could similarly highlight this as a prediction at best and offer further support for their position through the low television ratings of recent BCS bowl games and decreasing attendance at some BCS events. This information suggests consumers would prefer another alternative. 
A tremendous amount of evidence exists, which highlights confidence in another postseason arrangement and the fact that it could produce increased revenue for all Division I-FBS members. For example, Barry J. Brett and Roy Bell from the law firm Troutman Sanders (New York, New York) in their letter to the members in July 2009 estimated a playoff could produce $\$ 375$ million in one year, nearly double the 2009 BCS payout (Hearing on BCS, 2009). Former University of Michigan President James Duderstadt projected a possible 16 -team playoff could produce $\$ 3$ to $\$ 4$ billion over several years. Even BCS advocates, such as Commissioners Jim Delany (Big Ten) and John Swofford (ACC) acknowledged that the commercial potential of a playoff would be likely if spots were guaranteed to BCS-charter institutions (Competition in college, 2003; Determining a champion, 2005; Bowl Championship Series, 2009).

Ultimately, the information presented above shows the BCS arrangement and title game potentially exclude deserving teams from both BCS and non-BCS conferences and therefore imposing harm onto competitors and consumers of college football under the Sherman Antitrust Act. The BCS was clearly established as a commercial enterprise designed to make profits for primarily charter member institutions (Pruitt, 2009; Rogers, 2008). Furthermore, the BCS highlights the financial divide between BCS and non-BCS schools and that many anti-competitive outcomes occur as a result of the BCS arrangement (Schmit, 2007). The real chasm establishes artificial barriers erected by BCS involve coaching salaries and retention, facility conditions/standards, travel accommodations, student-athlete academic services, recruiting attractiveness, and the ability to procure and recondition top of the line equipment and other services. Claims made by the BCS that they produce a true national champion and the best bowl games for consumers are also not legitimate. Furthermore, it appears BCS advocates resist the idea of a less restrictive postseason arrangement because they want to protect their status as the elite of the FBS.

\section{The Lanham and Federal Trade Commission Acts}

From a slightly different perspective, the courts will also likely have to hear whether or not college football consumers asked for these products (Seifried \& Smith, 2011). The literature acknowledges they 
have and in an overwhelming fashion throughout the past several decades of college football (Nixon, 2009; Seifried, 2011; Seifried \& Smith, 2011; Warmbrod, 2004). Consumer protection laws aim to ensure accurate information is provided to the public and that false advertising is limited. The Lanham Act, passed in 1946, was developed to achieve this objective because it was designed to protect the public interest from deceptive trade practices through advertising. Specifically, section 43 (a) of the Act targets deceptive trade practices of commercial organizations and states:

a) Any person who, on or in connection with any goods or services, or any container for goods, uses in commerce any word, term, name, symbol, or device, or any combination thereof, or any false designation of origin, false or misleading description of fact, or false or misleading representation of fact, which-

a. is likely to cause confusion, or to cause mistake, or to deceive as to the affiliation, connection, or association of such person with another person, or as to the origin, sponsorship, or approval of his or her goods, devices, or commercial activities by another person, or

b. in commercial advertising or promotion, misrepresents the nature, characteristics, qualities, or geographic origin of his or her or another person's goods, services, or commercial activities, shall be liable in a civil action by an person who believes that he or she is or is likely to be damage by such act (15 U.S.C. $\$ 1125$ (a) 2006).

The plain reading of $\S 1125$ (a) provides consumers with the opportunity to challenge any advertisements they believe are fraudulent and misleading. It also provides competitive organizations the opportunity to establish a private cause when they too engage in similar commerce. Thus, the NCAA's non-BCS members or private citizens could challenge the BCS agreement as participating in unfair competition through false advertising the $\mathrm{BCS}$ as supporting a true national championship and the most entertaining games. Their claim would suggest they suffered significant injury related to their commercial interests to produce a quality product or output and that less restrictive means are available to meet their preferences.

The Federal Trade Commission Act similarly prompts the examination of consumer welfare provided by the BCS. Modified in 
2006, the Federal Trade Commission Act was created to assuage the public demand for more oversight related to business practices utilized in the greater marketplace (Allred, 2010). The modified 15 U.S.C. $\S 41-58$ (2006) essentially established it was a violation to " ... disseminate, or cause to be disseminated, any false advertisement... for the purpose of inducing, or which is likely to induce, directly or indirectly, the purchase in or having an effect upon commerce" (Section 52a). However, unlike the Lanham Act, the Federal Trade Commission Act provides no private cause opportunities for review and thus, depends on the desire of Congress to push for action and enforce penalties (Allred, 2010). The test to prompt the filing of a claim includes the material representation, omission, or practice of activities (e.g., advertisement and other extrinsic evidence) that are likely to mislead consumers (Allred, 2010).

To address the lack of private cause opportunities and support provided by the federal government, many states created unfair and deceptive acts or practices legislation (Mize, 2005; Sheldon \& Carter, 2009). Typically, these state-supported trade commission acts provide broad and flexible interpretations which are interpreted to favor public interests and thus allow private individuals and organizations to engage in litigation against those practices they perceive to be unfair and deceptive to consumers (Allred, 2010). Damages for most economic activities are offered in a variety of forms such as: a) cease and desist orders; b) attomey fees; c) compensatory damages; and d) treble and punitive damages (Allred, 2010; Sheldon \& Carter, 2009).

Courts will need to consider whether or not the BCS deceptively acts as a supplier to convince or promote itself (i.e., consumer transaction) to the public as the national championship event. The term "supplier" in this work follows the definition established in Utah Code to mean sellor, offeror, or broker "who regularly engages in, or enforces consumer transactions, whether or not he deals directly with the consumer" (Utah Code Ann. 2009, Section 3-6). The BCS appears to exist as a supplier under the broad interpretation of the definition. The BCS also appears to act as the offeror and sellor through its offer to sell those contests/games. As an example, television rights to the games are sold to organizations (e.g., Fox and ESPN) along with opportunities to join the contest as official sponsors/partner. Merchandise and apparel is also offered for public consumption in association with BCS events. Sweatshirts, logos, hats, and DVDs offered for a price prior to and after bowl games serve as excellent examples of this phenomenon. Online 
methods (e.g., check or credit card) to purchase products and services (i.e. travel) to both consumers and potential clients or partners allow the $\mathrm{BCS}$ to be seen as the broker, sellor, and offeror, and thus, ultimately as the supplier too.

The offer to attend (i.e., live or remote attendance) the BCS finale as the "National Championship Game" also lends credence to the previous claims along with the careful consideration of the various BCS bowl sites to select universities for its limited number of invitations. The bids provided by the various BCS bowl sites are brokered by the BCS because they assist in the invitation and creation of events for the universities, their athletic department personnel, alumni, and members of their fan nation (Allred, 2010). A consumer transaction results from the transfer of money or value through the "sale, assignment, award by chance, or other written or oral transfer or disposition of goods, services, or other property" (Utah Code Ann. 2009, Section 3-2). The BCS also invests a tremendous amount of money each year to maintain and improve its brand image and exposure to the public through active marketing campaigns, partnerships (e.g., Capital One), regular updates on its website, and the creation of news releases. Allred (2010) suggested more exposure equaled more business for the BCS and better health of those charter-member institutions and bowl sites to secure/maintain more revenue. Therefore, the business of the BCS is not centered on determining a true national champion but procuring money for a privileged few.

As a supplier, the BCS can be viewed as demonstrating consumer fraud because it knowingly and intentionally attempted to promote its series of games and the finale as possessing a certain performance standard or quality other games would not enjoy. Specifically, the BCS promoted its contests as the showing the best match-ups for college football fans and the most accomplished teams as part of those contests. Circumstantial evidence previously provided demonstrates the BCS regularly and knowingly violates this claim. Again, the BCS misrepresents its finale with regard to quality, style, and nature as the National Championship between college football's best two teams.

Champions should be identified through their ability to defeat all rivals in competition or a series of competitions complete with all willing, able, and qualified competitors (Allred, 2010). The BCS is not the result of a structure designed to give opportunities for all competitors to enjoy meaningful competition. The BCS National Championship 
Game instead misleads the public and consumers because it does not realistically provide for Division I (FBS) non-BCS charter schools to join the 'pool of consideration.' Again, preseason bias, obscure selection procedures, and an illegitimate formula mislead many consumers into believing the BCS champions are the most accomplished or best team in college football when this questionable at best. For example, the various components of the BCS typically do not demonstrate agreement about which two teams should be selected for the finale or which teams are qualified to be considered for other BCS games. Stern (2006) also statistically demonstrated considerable variation exists between the two human polls (i.e., media and coaches) and various computer algorithms used to create the BCS standings. Allred (2010) further noted late season wins and losses by teams and their opponents change the perspective of voters weekly. Traditional football powers also tend to receive more national television exposure than lesser accomplished programs which potentially help influence voters. Ultimately, the BCS becomes a beauty contest among the traditional powers without concern for the best available alternative in the consumer marketplace. Furthermore, it appears consumers suffer through the deceptive trade strategies and behaviors practiced by the charter membership of the BCS and this may be why the BCS is looked at with such contempt by members Congress and the public (Allred, 2010).

\section{Antitrust Speech within Congressional Activity}

In several Congressional hearings, some U.S. Senators and Representatives identified the BCS agreement and selection procedures as possibly violating Section 1 and 2 of the Sherman Antitrust Act (BCS or bust, 2003; The Bowl Championship Series, 2009; Competition in college, 2003; Determining a champion, 2005; Hearing on BCS, 2009). This point surfaced as a major point of contention among the various attendees at the hearings. The U.S. Congressmen generally speculated charter members of the BCS conspired to create the structure and arrangement of the BCS to reassure their continued financial success and respected image over their non-BCS colleagues (Nixon, 2009). This speculation even escalated to suggest that non-BCS schools were coerced into signing the current BCS agreement because non-BCS schools recognized a failure to do so would result in the alternative, no revenue from the BCS agreement, New Year's Day appearances or 
participation in those holiday festivities promoted by the bowls (Seifried \& Smith, 2011).

Interestingly, members of Congress and state legislatures examined this issue well enough to develop important governmental documents which support the establishment of an NCAA Division I (FBS) playoff or tournament in the interest of fundamental fairness (Nixon, 2009; Pruitt, 2009). As an example, the Georgia House of Representative in February of 2008 voted 151 to 9 adopt House Resolution 1034 which recognized the BCS as a "dysfunctional" system and that it was necessary to implement a playoff to determine the champion for college football (Georgia H. Res., 2008). At the federal level, the House of Representatives established H. Res. 1120 in 2008 and H. Res. 68 in 2009 to support this perspective. Specifically, House Resolution 68 (2009) was created to reinforce "... the establishment of an NCAA Division I Football Bowl Subdivision Championship playoff system in the interest of fairness and to bring parity to all NCAA teams" (p. 1). Co-sponsored by both Democrats and Republicans, H. Res. 68 (2009) emerged within the Committee on the Judiciary, and in addition to the Committee on Education and Labor. ${ }^{5}$ Interestingly, H. Res 68 formally recognized the rule of reason test required a less restrictive means to manage the Division I (FBS) postseason and those procompetitive benefits should be measured and weighed against anticompetitive effects under this analysis.

Democrats and Republicans also co-sponsored a bill to the Committee on Energy and Commerce known as the "College Football Playoff Act of 2009" which passed in December 2009. Better known as H. Res. 390, the bill prohibited the promotion of any game as the "National Championship" after January 31, 2011 unless that game was the result of an elimination tournament and included opportunities for entry or consideration from all Division I (FBS) conferences. Nixon (2009) also identified that the House of Representative with this action rejected the BCS and viewed it as an illegal restraint of trade which violated the Sherman Antitrust Act. Furthermore, the House of Representatives called on the United States Department of Justice Antitrust Division to investigate this claim and bring swift action onto the BCS to cease and desist their advertisement and promotion as

5 (i.e., Neil Abercrombie- Democrat [Hawaii], Jim Matheson- Democrat [Utah], Michael Simpson- Republican [Georgia], and Lynn Westmoreland- Republican [Georgia]) 
supporting the national championship contests associated with the Division I (FBS) (Nixon, 2009). Representative Bobby Rush (DemocratIllinois) voiced the bill helped "... ensure that the vision of a true college football champion, determined on the field of play, comes to fruition" and that "non-favored conferences" are not penalized by arbitrary rules and an inequitable distribution formula concerning postseason revenue (Rush, 2009, p. 2).

\section{Conclusion}

Prior to the establishment of the BCS, the twenty previous years of Fiesta, Orange, Rose, and Sugar Bowls inviting 160 schools from current $\mathrm{BCS}$ conferences and none from non-BCS leagues existed. Expectedly, BCS-charter institutions would argue that their sponsored agreement produces the championship game, interesting match-ups, and opportunities for non-BCS school, which consumers' desire. Furthermore, it serves to keep the season at a minimum number of games because university presidents and chancellors wish to avoid a longer extended season. However, the BCS arrangement has only slightly altered the postseason opportunities for non-BCS schools from what has historically occurred and has extended the bowl season to consume almost a month and into school spring academic calendars (e.g., 2010 Bowl season December 18-January 10). Not surprisingly, the President of the United States of America, Barack Obama, recently expressed if he could change one thing about sport he would want to see the Division I (FBS) institutions settle their national championship on the field with a playoff (Nixon, 2009; Pruitt, 2009; Seifried \& Smith, 2011). The likelihood of success by potential plaintiffs remains unclear. However, based on this information, there is a legitimate opportunity for plaintiffs to challenge the pro-competitive claims of the current BCS system and as violating antitrust and other consumer protection laws.

There is also a legitimate opportunity for the NCAA to do the right thing as a governing body. According to the NCAA mission, the organization's purpose is to promote "fair, safe, equitable, and sportsman-like conduct while being committed to the values of balance academic, social, and athletic experiences," while "enhancing the sense of community" at member institutions (NCAA Core Values, 2010, p.1). The fundamental values which shape the American landscaped also include equal opportunity and fair play (Allred, 2010). The BCS 
undermines these core principles of both the NCAA and America (Allred, 2010). There is no doubt that the traditional powers of college football anticipate and forecast they will lose the control of revenue and prestige through participation in a playoff. The status quo provides them with the ability to block non-BCS schools from sharing because the lucrative sponsors, who drive postseason opportunities, fear nationwide consumers will not pay attention to products which support non-BCS schools (Schmit, 2007). In essence, BCS advocates suggest the pools of money available from television ratings, sponsors, game attendees (i.e., live or remote) will dry up if a playoff is accepted involving non-BCS schools. Still, as previously mentioned antitrust courts may not likely accept this speculation unless it is real and concrete.

Interestingly, Moreland (2005) noted the BCS is technically a non-profit entity established to maximize profits for their members. However, the evidence shows it does not for all members. Therefore, potential judicial reviews would disregard any claims of nonprofit status made by the BCS due to precedent in United States $v$. Realty Multi-List (1980) and Board of Regents v. NCAA (1983). The NCAA also acts as a supervisor and certification official for Division I (FBS) postseason and not as an active manager seeking to assure those events are consistent with their mission and values statements. Thus, ignoring the BCS' operations from this perspective makes the NCAA cooperatively involved, albeit by default, with the BCS arrangement and selection procedures. Furthermore, the NCAA can be seen as supportive of the BCS' discrimination policies and commercialization when it could replace that entity to provide a more balanced and fair distribution system for postseason appearances and available revenue.

Finally, Pruitt (2009) claimed the BCS agreement is the result of compromise between colleges/universities, conferences, and bowls which could not "... otherwise be produced absent their consideration" (p. 125.). But do college football consumers really want and deserve this compromise and is this best to meet their preferences? The accomplishment of the $\mathrm{BCS}$ postseason arrangement fails to eliminate the consumer worries and demands for an alternative format (i.e. tournament) to identify a true champion. Therefore, it is remarkably similar to the previous bowl arrangement. Schmit (2007) offered the social importance of accepting a new format to embrace non-BCS schools into a postseason tournament would suggest the defeat of corporate driven decision-making and the meeting of consumer 
preferences. However, the courts may remain reluctant and potentially unwilling to examine this issue without a determined group of studentathletes, coaches, public officials, university advocates and representatives, media officials, and college football fans to fight for a better alternative postseason arrangement. Based on the evidence presented above these items suggest a significant amount of interstate commerce occurs as a result of the BCS product. Therefore, the topic is available for Congressional review and must submit to Congress' constitutional authority if they decide to act more aggressively or if other individuals bring notice to the courts.

\section{ABOUT THE AUTHOR}

Chad S. Seifried is an Assistant Professor in the School of Kinesiology at Louisiana State University. His research interests include Division I (FBS) postseason decision-making and organizational behavior including bowls, payouts, financial distribution, economic impact, legal issues.

\section{References}

2010-2011 BCS Media Guide (2010). The BCS Standings. Retrieved from http://a.espncdn.com/i/ncf/bcs/bcsguide2010b.pdf

2011-2012 Division I manual (2011). National Collegiate Athletic Association. Indianapolis, IN: Author.

Allred, P. (2010). From the BCS to the BS: Why "Championship" must be removed from the Bowl Championship Series. Utah Law Review, 1, 183-199.

BCS or bust: Competitive and economic effects of the BCS on and off the field: Hearing before the Committee on the Judiciary, Senate. $108 d$ Cong. $1^{\text {st }}$ Sess. (2003).

Board of Regents of the University of Oklahoma v. NCAA, 463 U. S. 1311 (1983).

The Bowl Championship Series: Money and issues of fairness at publicly financed universities (2009, May 1). House of Representatives, Subcommittee on Commerce, Trade, and Consumer Protection, Washington, D.C. Retrieved from http://energycommerce.house.gov/Press_111/20090501/transcript _20090501_ct.pdf. 
Brand, M. (2006, November 13). [Letter to Representative William Thomas, Chairman, House Committee on Ways and Means]. Retrieved from http://www.ncaa.org/.

California Dental Association v. FTC, 526, U.S. 756, 770 (1999).

Chicago Board of Trade v. United States, 246 U. S. 231 (1918).

College Football Playoff Act of 2009, H.R. 390, $111^{\text {th }}$ Cong. (2009).

College Football Playoff Act of 2008, H.R. 7330, $110^{\text {th }}$ Cong. (2008).

Competition in college athletic conferences and antitrust aspects of the

BCS: Hearing before Committee on the Judiciary, Senate. $108 \mathrm{~d}$ Cong. $1^{\text {st }}$ Sess. (2003).

Determining a champion on the field: A comprehensive review of the $B C S$ and postseason college football: Hearing before Subcommittee on Commerce, Trade, and Consumer Protection, House of Representatives. $109 \mathrm{~d}$ Cong. $1^{\text {st }}$ Sess. (2005).

Duderstadt, J. J. (2003). Intercollegiate athletics and the American university: A university president's perspective. Ann Arbor, MI:

University of Michigan Press.

The Federal Trade Commission Act of 1914 (15 U.S.C $\S \S 41-58,2006$ ).

Fenasci, B. P. (2004). An antitrust analysis of college football's Bowl Championship Series, Loyola Law Review, 50, 967-996.

Fisher, B. D., \& Phillips, M. J. (2003). The legal, ethical and regulatory environment of business (8th ed.). Cincinnati, $\mathrm{OH}$ : Thomson/South-Western.

Fizel, J. L. \& Bennett, R. W. (2001). College sports. In W. Adams \& J. Brock (Eds.). The structure of American industry. (pp. 323-325). Upper Saddle River, NJ: Pearson/Prentice.

Fulks, D. L. (2009). Revenues and expenses, profits and losses of Division IA intercollegiate athletic programs. NCAA.org. Retrieved from

http://www.ncaapublications.com/ProductsDetailView.aspx?sku= RED12ONLINE.

Georgia H. Res. 1034, Georgia General Assembly. (2008).

Hearing on Bowl Championship Series: Is it fair and in compliance with antitrust law? (2009, July 7). Senate, Subcommittee on Antitrust, Competition Policy and Consumer Rights, Washington, D.C. Retrieved from

http://judiciary.senate.gov/hearings/hearing.cfm?id=3951.

H. Res. $68,111^{\text {th }}$ Cong. (2009). 
International Boxing Club of New York, Inc. v. United States, 358, U.S. 242, 250-51 (1959).

Lanham (Trademark) Act (15 U.S.C. $\$ 1125$ (a) 2006).

Miles, W. M., Fowks, G. T., \& Coulter, L. O. (2010). AccuV college football ranking model. Journal of Quantitative Analysis in Sports, 6(3), 1-15.

Mize, J. (2005). Fencing off the path of least resistance: Re-examining the role of little FTC Act actions in the law of false advertising. Tennessee Law Review, 72, 653-670.

Moreland, D. S. (2005). The antitrust implications of the Bowl Championship Series: Analysis through analogous reasoning. Georgia State Law Review, 21, 721-748.

Myers, D. K. \& Horowitz, I. (1996). Private enforcement of the antitrust laws works occasionally: Board of Regents of the University of Oklahoma v. NCAA, a case in point, Oklahoma Law Review, 48, 669-676.

National Collegiate Athletic Association (2010, June 29). Core values. Retrieved from http://www.ncaa.org/wps/wcm/connect/public/ncaa/about+the+nc aa.

National Collegiate Athletic Association (2010, April 10). BCS revenue distribution. Retrieved from http://www.ncaa.org/wps/wcm/connect/a547f60042494ced83f8d $7132 \mathrm{e} 10 \mathrm{~b} 8 \mathrm{df} / \mathrm{BCS}++$ Revenue + Distribution $+\mathrm{by}+$ Conference +200 9.

10.pdf?MOD=AJPERES\&CACHEID $=\mathrm{a} 547 \mathrm{f} 60042494 \mathrm{ced} 83 \mathrm{f} 8 \mathrm{~d} 7$ $132 \mathrm{e} 10 \mathrm{~b} 8 \mathrm{df}$.

National Collegiate Athletic Association (2010, February 2). Summary of revenue and expenses by conference. Retrieved from http://www.ncaa.org/wps/wcm/connect/public/ncaa/pdfs/postseas on + football/bowl + excess + revenue + expenses + by + conference +20 $09+10$.

National Collegiate Athletic Association (2009). NCAA membership requirements.

http://ncaa.org/wps/wcm/connect/def326804e0d521599f2f91ad6f c8b25/chart_memreq.pdf?MOD=AJPERES\&CACHEID $=$ def326 $804 \mathrm{e} 0 \mathrm{~d} 521599 \mathrm{f} 2 \mathrm{f} 91 \mathrm{ad} 6 \mathrm{fc} 8 \mathrm{~b} 25$.

NCAA v. Board of Regents of the University of Oklahoma, 468 U.S. 85 (1984). 
Nixon, L. B. (2009). Playoff or bust: The Bowl Championship Series debate hits Congress again. St. Thomas Law Review, 2l(3), 365380.

Non-BCS conferences get record payout. (2010, January 27). Retrieved from http://sports.espn.go.com/dallas/ncf/news/story?id=4856300

Northern Pacific Railway Company v. United States, 356 U.S. 1 (1958).

Pruitt, C. (2009). Debunking a popular antitrust myth: The single entity rule and why college football's Bowl Championship Series does not violate the Sherman Antitrust Act. Texas Review of Entertainment and Sport Law, 11, 125-151.

Rogers, C. P. (2008). The quest for number one in college football: The revised Bowl Championship Series, antitrust, and the winner take all syndrome. Marquette Sports Law Review, 18, 285-307.

Rush, R. (2009, December 9). Manager's amendment to H.R. 390: College football playoffs act of 2009. Energy and Commerce Subcommittee on Commerce, Trade and Consumer Protection, Retrieved from http://democrats.energycommerce.house.gov/Press_111/2009120 9/rush_opening.pdf.

Schmit, J. D. (2007). A fresh set of downs? Why recent modifications to the Bowl Championship Series still draw flag under the Sherman Act. Sports Lawyers Journal, 14, 219-254.

Seifried, C.S. (2011). The opinions of administrators on the Division I (Football Bowl Subdivision) playoff issue: A content analysis of their perspectives pre-BCS from popular media sources and the NCAA News. Sport History Review, 42, 29-55.

Seifried, C. S. (2012). A historical review of the Division I (Football Bowl Subdivision) playoff issue pre-BCS: A content analysis of the core stakeholders perspective from popular media sources and the NCAA News. Journal of Issues in Intercollegiate Athletics, 5, 96-118.

Seifried, C. S. \& Smith, T. (2011). Congressional hearings and the Division I (Football Bowl Subdivision) postseason arrangement: A content analysis on letters, and testimonies. Journal of Issues in Intercollegiate Athletics, 4, 1-23.

Sheldon, J. A. \& Carter, C. L. (2009). Unfair and deceptive acts and practices $\left(7^{\text {th }}\right.$ ed.). Boston: National Consumer Law Center.

The Sherman Anti-Trust Act of 1890 (15 U.S.C.A. $\S \S 1$ et seq.). 
The state of Division I college athletics: Is the system flawed? Legal ramifications of the Bowl Championship Series and conference alignment. (2005). Vanderbilt Journal of Entertainment Law and Practice, 7, 461-482.

Stekler, H. O., Sendor, D., \& Verlander, R. (2010). Sports forecasting. International Journal of Forecasting, 26(3), 445-447.

Stern, H. S. (2006). In favor of a quantitative boycott of the Bowl Championship Series. Journal of Quantitative Analysis in Sports, 2(1),

Thieme, E. (2007). You can't win'em all: How the NCAA's dominance of the college basketball postseason reveals there will never be an NCAA football playoff. Indiana Law Review, 40(2), 453-78.

TV Ratings. (2011, February 28). Retrieved from http://www.bcsfootball.org/news/story?id=4819384.

United States v. Brown University, 5 F.3d 658 ( $3^{\text {td }}$ Cir. 1993).

United States v. Realty Multi-List, Inc. 629 F.2d 1351 ( $5^{\text {th }}$ Cir. 1980).

Utah Code Ann. § 13-11 (2009).

Warmbrod, J. M. (2004). Antitrust in amateur athletics: Fourth and long: Why non-BCS universities should punt rather than go for an antitrust challenge to the Bowl Championship Series. Oklahoma Law Review, 57, 333-379.

Werden, G. J. (2007). Monopsony and The Sherman Act: Consumer welfare in a new light, Antitrust Law Journal, 74, 707, 721-29.

West, B. T. \& Lamsal, M. (2008). A new application of linear modeling in the prediction of college football bowl outcomes and the development of team ratings. Journal of Quantitative Analysis in Sports, 4(3), 1-19. 